\title{
Freedom of Expression and the Construing of Defamation Under the Ethiopian Civil and Criminal Law
}

\author{
ANDUALEM AMBAYE \\ LLB in Law from Gondar University, LLM in International Law from ECSU. \\ High Court Judge (acting) at Gamo Zone, Ethiopia
}

\begin{abstract}
Defamation is defined as the act of communication of a false statement that harms the reputation of a person, business, product, group, government, religion, or nation ${ }^{1}$. To constitute a defamation, an act must generally be intentional whether it is truth or false statement and must have been made to someone other than the person defamed. Some common law jurisdictions also distinguish between spoken defamation, called slander, and defamation in other media such as printed words or images, called libel ${ }^{2}$. Under this work defamation is seen from its liability aspects against the free use of freedom of expression. The laws in relation to freedom of expression such as the ICCPR, ICESCR, UDHR, and the municipal laws such as: the FDRE Constitution, the Press and Media laws, the Criminal and Civil laws of the country that expressly or tacitly dealing with freedom of expression and the consequence of defamation.
\end{abstract}

DOI: $10.7176 / \mathrm{JLPG} / 109-01$

Publication date:May $31^{\text {st }} 2021$

\section{The Dichotomy of Freedom of Expression and Defamation as a Limitation}

Most of the rights in international human right documents are defined to be a human innate right that are given as a born right leading to the free exercising of such rights with full freedom. The conception that such rights are endowed to us by nature will also entails and presupposes the non-interference of any third party over such naturally conferred rights and freedoms. However, for reasons of collective interest and for general public goods the exercise of freedoms and rightscan be limited in some grounds. And freedom of expression is one of the rights that can be limited to protect other higher interest in comparison to the individual interest.

An individual on the full exercise of his human right of freedom of expression, he/she is liable for his speech might inflict on the honor and reputation of other individuals or groups. Expressing one's ideas freely without anyone's interference sometimes entails the risk of the probability or danger of damaging others' reputation. This implication leads to the issue of how to reasonably reconcile the conflict between freedom of expression and defamation as a legal limitation thereof. This issue is about the limit of the illegality of free expressions of ideas. While human rights as a guiding principle holds absolute values that cannot be restricted, freedom of expression is a right with exceptions to that guiding principle to be regarded as having an absolute value. This form of freedom represents a form of right to freedom that is only a 'means' to realize human rights. Balance between freedom of expression and prevention of defamation is also consistent with the Anti-over restriction principle ${ }^{3}$. Abstaining from violating others' rights by freewill right is what a moral people should abide with.

\section{Defamation and its Legal Effects in General}

Many nations have both criminal penalties and civil liabilities for act of defamation on the manner of distinguishing whether such an offense has occurred. Depending up on the style of the legal system they follow, countries defamation laws can be either entailing civil or criminal liability only or holding both civil and criminal liability. For instance, in the legal system in Ireland, defamation is treated as a crime rather than a civil wrong $^{4}$. And it is only of civil liability in some common law countries that leads to claiming a right under the tort laws 5 . Whereas, in some other countries defamation entails both civil and criminal liability. And one for such an example is the Ethiopian legal system. ${ }^{6}$ The criminal liability most of the time end up with arresting and/or punishing with fine of the perpetrator and taking other measures to capacitate the defamed person to regain the status what the person has been before the defamation.

Dependingon the nature and type of the defamation, the depth of the liability also ranges from simple and

${ }^{1}$ LeRoy Miller, Roger (2011). Business Law Today: The Essentials. United States: South-Western Cengage Learning. p. 127. ISBN 1-13319135-5.

${ }^{2}$ Linda L. Edwards, J. Stanley Edwards, Patricia Kirtley Wells, Tort Law for Legal Assistants, Cengage Learning, 2008 , p. 390.

${ }^{3}$ Chang, Y.I., 2013. Freedom of Expression and Defamation. Journal of Convergence Information Technology, 8(14), p.598.

4 "The Law Reform Commission of Ireland-Consultation Paper on the Civil Law of Defamation (see item 360 in bold)". Archived from the original on 8 August 2009.

${ }^{5}$ Benenson, R (1981). "Trial of John Peter Zenger for libel". The CQ Researcher. Retrieved 2010-11-08.

${ }^{6}$ The Ethiopian Criminal Code and the Civil Code provisions dealing with defamation and its civil and criminal consequence. 
petty to more constructed punishment of criminal liability either. The civil liability on the other hand is executed either by way of compensation of the defamed person, republication of the defamatory statement or action by corrected means.

On the UDHR ${ }^{1}$ whereas, disregard and contempt for human rights have resulted in barbarous acts which have outraged the conscience of mankind, and the advent of a world in which human beings shall enjoy freedom of speech and belief and freedom from fear and want has been proclaimed as the highest aspiration of all the people. The ICCPR and ICESCR take cognizantly freedom of expression as it is conferred to individuals to be exercised while respecting the rights of others. The ICCPR in its provisions states that everyone freedom of expression without interference and this right shall include freedom to seek, receive and impart information and ideas of all kinds, regardless of frontiers, either orally, in writing or in print, in the form of art, or through any other media of his choice. However, the exercise of such rights carries with it special duties and responsibilities ${ }^{2}$. It may therefore be subject to certain restrictions, but these shall only be such as are provided by law and are necessary for respect of the rights or reputations of others, the protection of national security or of public order, or of public health or morals. The ICESCR ${ }^{3}$, on its motives in the preamble, contemplates freedom of expression as a means to assure the economic, social, and cultural rights and as way of enjoying freedom from fear and want. And this international legal instruments dealing with freedom of expression are part of the municipal laws of many states in the world and Ethiopia is one of such states.

\section{Defamation under Ethiopian Laws}

Under the national legal system in Ethiopia there are different laws dealing with defamation as one legally stipulated limitation of the free exercise of freedom of expression. The FDRE constitution states that freedom of expression can be limited by laws guided mainly to protect the national and public interest, security, and for morality reasons ${ }^{4}$. As per this provision, legal limitation on freedom of expression can be laid down to protect the well-being of the youth, thehonor and reputation of individuals and any propaganda for war as well as the public expression of opinion intended to injure human dignity shall be prohibited by law.

The FDRE criminal code also in its provisions dealing with crimes against reputation and honor art.607 states that crimes against honor or reputation can be committed on individuals or juridical persons, on living person, deceased person or on absent person ${ }^{5}$. The act of defamation is punishable no matter what the rank or social status of the criminal or the victim is. The court in determining the criminal punishment will take in to account the extent of publicity or circulation of the defamation, the position of the injured, and the gravity of the crime.

Defamation can be committed by direct or indirect way by means of word of mouth, by sound, in writing, image, sign, by gesture or by any other means. ${ }^{6}$ The act of recording, production, emission, communication, projection, graphical visual and aural imparting is all punishable under this provision. If such a crime is committed by the juridical person, the punishment is fine imposition and in some cases the arresting of the directors, managers, inspectors, proxies and agents or staff members is also included under the criminal code as criminal liability for defamation. However, many of the provisions in the criminal code is restrictive and claw back clauses to exercise freedom of expression. None of the ways of communicating and imparting information and ideas are free from and left excluded from entailing criminal liability and this creates fear of media and will undermine the development of art and the expansion of the culture of freedom of expression.

Even if the stated word is truthful cannot be a defense for the criminal if he made the utterance or the action with the intent to defame the person's reputation and honor. However, this type of stipulation may by itself be able to avoid individuals from telling truth of what has been done and paves way for wrong doers to continue with their wrong acts. And this will have a worst effect if it is for the authorities who are doing wrong at the expense of the public interest. There is also no parameter to prove whether the person has uttered what is truth with the motive to affect others. Under the civil liability of defamation the civil code states defamation as a moral injury and the court may order compensation by way of redress to the plaintiff where different types of defamation has been made on the individuals or juridical persons. ${ }^{7}$ The court may order the corrected publicity to be made at the expense of the defendant in the alike manner as the defamation was made. Thus, the legally recognized restriction over the free exercise of freedom of expression has also the cost implication over the one who used his freedom of expression beyond what is restricted. Here we have the overlapping interest of the doer freedom of expression on one hand and the victims honor and reputation as human right to be respected on the

\footnotetext{
${ }^{1}$ The Universal Declaration of Human Rights

${ }^{2}$ Article 19 of the International Covenant on Civil and Political Rights.

${ }^{3}$ The preamble of the International Covenant on Economic, Social, and Cultural Rights.

${ }^{4} 10$ Article 29(6) of the constitution of the Federal Democratic Republic of Ethiopia

${ }^{5} 11$ Article 608 and the following articles under the Criminal Code of the Federal Democratic Republic of Ethiopia

${ }^{6} 12$ Ibid art. 608

${ }^{7} 13$. Article 2109 and the following in the Civil Code of Ethiopia
} 
other. Thus, in order to compromise the competing interests there should be a clear and precise limit of restricted points of freedom of expression. The proportionality analysis which requires that any limitation imposed on a right be proportionate to the legitimate aim being perused is employed to distinguish acceptable and unacceptable limitations on human rights. The press laws of the nation, even though it asserts to build democratic order in Ethiopia as purpose in its preamble, the restrictions and its prohibitions of the media freedom makes it to back fire its own purpose. ${ }^{1}$ Therefore, some form of limitation on the limitations themselves is necessary.

\section{Conclusion}

Freedom of expression is one of the rights conferred because of human nature and it must have been enjoyed freely. However, on the exercise of one's freedom the abusing of others right is inevitable. That is why laws regulating freedoms in international and domestic legal instruments has come up with some exception over the free exercise of the rights. This is to protect others interest in comparison to the individual interest. This intersecting ideas might leads to the issue of how to reasonably reconcile the conflict between freedom of expression and defamation as a legal limitation. There are laws governing such issues in different countries. In Ethiopia we have both criminal and civil laws dealing with defamation as a limitation of freedom of expression even if the laws are more restrictive. Therefore, it is quit essential for the states to be careful in putting limitations for such fragile right in order to protect it from disappearance by limitless limitations.

\section{Bibliography}

Benenson, R (1981). "Trial of john peter zenger for libel". The CQ Researcher. Retrieved 2010-11-08.

Chang, Y.I., 2013. Freedom of Expression and Defamation. Journal of Convergence Information Technology.

Edwards, Linda L. Stanley Edwards, J. Kirtley Wells, Patricia. Tort Law for Legal Assistants, Cengage Learning, 2008.

Miller, LeRoy. Roger. Business Law Today: The Essentials. United States: South-Western Cengage Learning, 2011.

"The Law Reform Commission of Ireland - Consultation Paper on the Civil Law of Defamation (see item 360 in bold)". Archived from the original on 8 August 2009.

The Constitution of the Federal Democratic Republic of Ethiopia

The Criminal Code of Ethiopia

The Civil Code of Ethiopia

The International Covenant on Civil and Political Rights.

The International Covenant on Economic, Social, and Cultural Rights.

The Mass Media and Access to Information Proclamation No. 590/2008

The Universal Declaration of Human Rights

\footnotetext{
${ }^{1}$ The preamble of Freedom of the Mass Media and Access to Information Proclamation No. 590/2008
} 